\title{
Effect of Phytohormones on the Composition of Sambucus ebulus Leaf Essential Oil
}

\author{
Alireza Feizbakhsh ${ }^{1}$, Haniyeh Pazoki ${ }^{1}$, Vahid Mohammadrezaei $^{1}$ and \\ Mohammad Ali Ebrahimzadeh ${ }^{2 *}$ \\ ${ }^{1}$ Department of Chemistry, Islamic Azad University, Central Tehran Branch, Tehran, ${ }^{2}$ Traditional and Complementary Medicine \\ Research Center, Mazandaran University of Medical Sciences, Sari, Iran
}

*For correspondence: Email: zadeh20@yahoo.com; Tel: +98-151-3543081-3; Fax: +98-151-3543084

\begin{abstract}
Purpose: To evaluate the effect of growth hormones - naphthalene acetic acid (NAA) and indole-3acetic acid (IAA) - on the essential oil of Sambucus ebulus leaf.

Methods: The leaves of S. ebulus were sprayed three times in one week with distilled water (as control) or with a solution of either NAA or IAA (150 ppb). Following the treatment, the leaves were collected from each of the plant and dried in the dark in a dry environment. The essential oil content of the leaves was obtained by hydrodistillation and analyzed by gas chromatography (GC) and GC-mass spectrometry (GC-MS)

Results: Sixty constituents were identified in the plant oil, some of which could have been responsible for the plant's biological and/or toxicological activities. The results indicate that NAA and IAA exerted significant effect on the composition of the essential oil, increasing some components and decreasing some others significantly. In some cases, certain compounds were eliminated completely from the oil. Conclusion: The use of phytohormones seems a useful strategy for modifying the composition of the essential oil in plants.
\end{abstract}

Keywords: Essential oil; Indole-3-acetic acid; Phytohormones, 1-Naphthaleneacetic acid; Sambucus ebulus.

Tropical Journal of Pharmaceutical Research is indexed by Science Citation Index (SciSearch), Scopus, International Pharmaceutical Abstract, Chemical Abstracts, Embase, Index Copernicus, EBSCO, African Index Medicus, JournalSeek, Journal Citation Reports/Science Edition, Directory of Open Access Journals (DOAJ), African Journal Online, Bioline International, Open-J-Gate and Pharmacy Abstracts

\section{INTRODUCTION}

Four species of the genus Sambucus (Caprifoliaceous) grow in Iran. Of these species, $S$. ebulus extensively grows in the northern regions of Iran [1]. Iranian traditional medicine uses the leaves and rhizomes of $S$. ebulus in treating some inflammatory problems such as, bee and nettle bites, arthritis, and a sore-throat [2]. It has been reported to be an insect repellent, anti-hemorrhoid, anti bacterial toward Helicobacter pylori, useful in the treatment of burns and infectious wounds, edema, eczema, urticaria, the common cold and rheumatism [3]. Recently good antioxidant activities were reported [4].

Phytohormones play an important role in the regulation of germination, growth, reproduction, and protective responses of plants against stress. Mass spectrometry (MS) is the most powerful tool for the determination of phytohormones due to its high sensitivity and selectivity. The use of GC-MS for this purpose has also been reported [5]. 
Indole-3-acetic acid (IAA) is the major plant growth hormone and is involved in the regulation of almost every step of plant development [6]. Naphthalene acetic acid (NAA) is widely employed in agriculture as a plant growth regulator. NAA prevents premature flowering, fruit drop and controls re-growth of tree sprouts after trimming.

In this study, the effect of growth hormones (NAA and IAA) on the chemical composition of volatile oils were evaluated because it seems that some compounds in the leaf may play a role in some biological and/or toxicological activities that have been reported previously for $S$. ebulus.

\section{EXPERIMENTAL}

\section{Chemicals}

IAA and NAA were purchased from Merck (Germany). The structures of the two phytohormones are shown in Figure 1.<smiles>O=C(O)Cc1c[nH]c2ccccc12</smiles><smiles>O=C(O)Cc1cccc2ccccc12</smiles>

Indole-3-acetic acid (IAA)

Naphthalene acetic acid (NAA)

Figure 1: Structures of NAA and IAA.

\section{Plant materials and treatments}

S. ebulus plant was collected from the suburb of Sari, Mazandaran Province, north of Iran, in August 2009 and identified by $\mathrm{Dr}$ B. Eslami (Department of Biology, Islamic Azad University of Qhaemshahr, Iran). A voucher specimen (no. 382) was deposited at the Herbarium of the Sari School of Pharmacy.

The experimental work was divided into 3 parts. The leaves of $S$. ebulus were sprayed three times in one week with distilled water (control) or a solution of either NAA or IAA (150 ppb). Following the treatment, the leaves were collected from each of the plants and dried in the dark and a non-humid environment. The conditions under which the treatments were carried out were the same for the duration of the experiment. All experiments were repeated thrice.

\section{Isolation of the Essential Oil}

The air-dried leaves were subjected to hydrodistillation, using a Clevenger-type apparatus for $4 \mathrm{~h}$. The oil obtained was dried over anhydrous sodium sulfate and stored in a sealed vial at a low temperature before analysis. The oils were analyzed using GC and GC/MS analysis.

\section{Gas chromatography (GC)}

Gas chromatographic analysis was carried out on a Hewlett Packard 6890N GC system with FID detector and a HP-5 MS $(30 \mathrm{~m} \times 0.320 \mathrm{~mm})$ capillary column. The column temperature was kept at $60^{\circ} \mathrm{C}$ for $20 \mathrm{~min}$ and programmed to $220^{\circ} \mathrm{C}$ at a rate of $5^{\circ} \mathrm{C} / \mathrm{min}$, and kept constant at $220^{\circ} \mathrm{C}$ for $20 \mathrm{~min}$. The injector and detector temperature was $270^{\circ} \mathrm{C}$. The injection volume was $1 \mu \mathrm{L}$. Helium was used as a carrier gas at a flow rate of $1 \mathrm{ml} / \mathrm{min}$.

Gas chromatography-mass spectrometry (GC-MS)

GC-MS analysis was performed using a HewlettPackard 5973N mass selective detector connected to an HP 6890N gas chromatograph. The same capillary GC conditions as described above were used. MS measurement was carried out at $70 \mathrm{eV}$.

\section{Identification of constituents}

The components of the oil were identified by their retention times, retention indices relative to $\mathrm{C}_{9}$ $\mathrm{C}_{28} n$-alkanes, computer matching with AUTOINT 1. E library and comparison of their mass spectra with those of authentic samples or with data already available in the literature [7]. The composition of the identified compounds was computed from the GC peak area without any correction factor and was calculated relatively.

\section{RESULTS}

Hydrodistillation of the dried leaves of $S$. ebulus resulted in a light yellowish oil with a yield of $0.1 \% \mathrm{v} / \mathrm{w}$. As shown in Table 1(a), (b) and (c), sixty components were identified in the oil, representing $97.31 \%$ of its total content. Longifolen was eradicated from the plant leaves treated with IAA when compared with control. On the other hand, NAA increased its content about 5 times. Both NAA and IAA substantially increased $\gamma$ - elemene in plant oil. $\delta$ - Elemene 
Table 1(a): Chemical composition of the essential oils of $S$. ebulus leaf (control group), naphthalene acetic acid (NAA) - and indole-3-acetic acid (IAA)-treated leaf treated)

\begin{tabular}{|c|c|c|c|c|c|}
\hline \multirow[t]{2}{*}{ No. } & \multirow[t]{2}{*}{ Component } & \multirow[t]{2}{*}{$\mathbf{K I}$} & \multirow{2}{*}{$\begin{array}{l}\text { S. ebulus } \\
\text { Area (\%) }\end{array}$} & \multirow{2}{*}{$\begin{array}{c}\% \text { IAA } \\
150 \text { ppb }\end{array}$} & \multirow{2}{*}{$\begin{array}{c}\% \text { NAA } \\
150 \text { ppb }\end{array}$} \\
\hline & & & & & \\
\hline 1 & $\beta$-Pinene & 976 & 0.57 & & \\
\hline 2 & $\alpha$-Terpinene & 1012 & 0.28 & & \\
\hline 3 & Linalool oxide & 1062 & 0.74 & 0.64 & \\
\hline 4 & $\alpha$-Thujone & 1094 & 1.19 & 0.94 & \\
\hline 5 & $\beta$-Thujone & 1101 & 0.81 & 0.95 & \\
\hline 6 & Ocimene oxide & 1110 & 1.16 & 1.38 & \\
\hline 7 & Ocimenone & 1124 & 0.38 & & \\
\hline 8 & Camphor & 1129 & 0.76 & 1.45 & \\
\hline 9 & Iso pulegol & 1135 & 0.09 & & \\
\hline 10 & Pino carvone & 1140 & 0.23 & & \\
\hline 11 & Iso borneol & 1147 & 0.92 & 1.21 & \\
\hline 12 & Borneol & 1156 & 0.58 & & \\
\hline 13 & Terpinen-4-ol & 1167 & 2.39 & 2.12 & \\
\hline 14 & Myrtenal & 1174 & 0.33 & & \\
\hline 15 & a-Terpineol & 1178 & 1.45 & 2.12 & \\
\hline 16 & Myrtenol & 1184 & 0.64 & & \\
\hline 17 & Verbenone & 1191 & 1.19 & 1.19 & \\
\hline 18 & Fragranol & 1196 & 0.44 & & \\
\hline 19 & Trans carveol & 1200 & 0.27 & & \\
\hline 20 & Cis carveol & 1211 & 3.86 & 5.06 & \\
\hline 21 & Pulegol & 1215 & 0.11 & & \\
\hline 22 & Carvone & 1218 & 0.5 & & \\
\hline 23 & Pulegone & 1220 & 0.98 & 0.88 & \\
\hline 24 & Chavicol & 1229 & 2.01 & 2.37 & \\
\hline 25 & Geraniol & 1236 & 1.52 & 0.69 & 1.26 \\
\hline 26 & Geranial & 1245 & 0.95 & 1.49 & 0.7 \\
\hline 27 & Iso estragol & 1260 & 1.39 & & \\
\hline 28 & Safrol & 1269 & 0.19 & & 0.59 \\
\hline
\end{tabular}


Table 1(b): Chemical composition of the essential oils of $S$. ebulus leaf (control group), Naphthalene acetic acid (NAA) - and indole-3-acetic acid (IAA)-treated leaf

\begin{tabular}{|c|c|c|c|c|c|}
\hline \multirow[t]{2}{*}{ No. } & \multirow[t]{2}{*}{ Component } & \multirow[t]{2}{*}{ KI } & \multirow{2}{*}{$\begin{array}{l}\text { S. ebulus } \\
\text { Area (\%) }\end{array}$} & \multirow{2}{*}{$\begin{array}{l}\% \text { IAA } \\
150 \text { ppb }\end{array}$} & \multirow{2}{*}{$\begin{array}{l}\% \text { NAA } \\
150 \text { ppb }\end{array}$} \\
\hline & & & & & \\
\hline 29 & Bornyl ac & 1272 & 0.92 & & \\
\hline 30 & Carvacrol & 1281 & 0.72 & & \\
\hline 31 & Piperitone & 1286 & 1.24 & & 2.07 \\
\hline 32 & Cis-pinocarvyl ac & 1293 & 1.24 & & \\
\hline 33 & Myrtenyl ac & 1300 & 1.05 & & 0.51 \\
\hline 34 & Trans-verbenol ac & 1308 & 3.74 & 1.85 & 0.66 \\
\hline 35 & Trans carvyl ac & 1318 & 2.32 & & 1.87 \\
\hline 36 & Eugenol & 1332 & 2.05 & 1.76 & \\
\hline 37 & $\delta$-Elemene & 1339 & 2.32 & 0.98 & \\
\hline 38 & a-Cubebene & 1358 & 5.22 & 6.69 & \\
\hline 39 & Geranyl ac & 1363 & 5.65 & 5.73 & \\
\hline 40 & a-Bourbonene & 1376 & 3.85 & 4.85 & \\
\hline 41 & a-Copaene & 1379 & 1.88 & & \\
\hline 42 & $\beta$-Cubebene & 1388 & 0.29 & & \\
\hline 43 & Iso-longifolene & 1392 & 1.93 & 1.36 & \\
\hline 44 & Cyperene & 1404 & 3.13 & 3.51 & \\
\hline 45 & Longifolene & 1408 & 0.28 & & 1.35 \\
\hline 46 & $\beta$-Gurjunene & 1412 & 0.84 & & \\
\hline 47 & $\beta$-Caryophyllene & 1418 & 2.14 & 2.93 & \\
\hline 48 & $\beta$-Caryophyllen oxide & 1425 & 3.28 & 1.96 & \\
\hline 49 & ү-Elemene & 1434 & 0.99 & 3.88 & 4.23 \\
\hline 50 & Aromadendrene & 1440 & 1.77 & 12.09 & \\
\hline 51 & Dehydro aromadendrane & 1458 & 0.72 & & 4.78 \\
\hline 52 & Germacrene D & 1480 & 6.89 & & \\
\hline 53 & $\beta$-Selinene & 1483 & 0.66 & 7.79 & \\
\hline 54 & Epi- cubebol & 1491 & 0.25 & & 1.38 \\
\hline 55 & $\beta$-Bisabolene & 1507 & 11.4 & & 4.64 \\
\hline 56 & Cubebol & 1513 & 0.81 & & \\
\hline
\end{tabular}

$\mathrm{KI}=$ Kovats index on HP-5 column 
Table 1(c): Chemical composition of the essential oils of $S$. ebulus leaf (control group), Naphthalene acetic acid (NAA) - and indole-3-acetic acid (IAA)-treated

\begin{tabular}{|c|c|c|c|c|c|}
\hline \multirow[t]{2}{*}{ No. } & \multirow[t]{2}{*}{ Component } & \multirow[t]{2}{*}{ KI } & \multirow{2}{*}{$\begin{array}{l}\text { S. ebulus } \\
\text { Area (\%) }\end{array}$} & \multirow{2}{*}{$\begin{array}{l}\% \text { IAA } \\
150 \text { ppb }\end{array}$} & \multirow{2}{*}{$\begin{array}{c}\% \text { NAA } \\
150 \text { ppl }\end{array}$} \\
\hline & & & & & \\
\hline 57 & ס-Cadinene & 1521 & 1.66 & 0.67 & \\
\hline 58 & Germacrene B & 1557 & 0.18 & & 1.28 \\
\hline 59 & Caryophyllen epoxide & 1565 & 0.51 & & \\
\hline 60 & Caryophyllenol I & 1650 & 1.45 & 0.91 & 8.38 \\
\hline 61 & $\beta$-Bourbonene & 1386 & & 1.27 & \\
\hline 62 & a-Caryophyllen oxide & 1416 & & 0.87 & \\
\hline 63 & a-Humelene & 1453 & & 5.41 & 1.85 \\
\hline 64 & Y-Muurolene & 1473 & & & 1.13 \\
\hline 65 & Selinen-y & 1527 & & & 17.07 \\
\hline 66 & Copa borneol & 1605 & & & 3.72 \\
\hline 67 & Iso spathulenol & 1628 & & & 8.73 \\
\hline 68 & a-Cadinol & 1639 & & & 0.89 \\
\hline 69 & Caryophyllenol II & 1661 & & & 4.77 \\
\hline \multirow[t]{2}{*}{70} & Farnesal & 1670 & & & 1.47 \\
\hline & & Total & 97.31 & & \\
\hline
\end{tabular}

was eradicated from the leaves treated with NAA but decreased by IAA (2.32 for control vs 0.98 for treated). Aromadendrene was increased 7 times in content by treating with IAA, compared with control while NAA eradicated it completely. Dehydroaromadendrene was dramatically increased by NAA ( 0.72 vs 4.78 for control and test, respectively); on the other hand, IAA eradicated it completely. $\beta$-selinene elevated 12 times by IAA treatment while NAA eradicated it completely in treated plants.

a-Humulene was not detected in control group but both NAA and IAA significantly induced production of $\alpha$-Humulene in treated plants. IAA increased trans-caryophyllene conyents but NAA eradicated it completely. $\beta$ - caryophyllene oxide was decreased by INN and eradicated it in those treated with NAA. As a result of treatment, cis pinocarvyl acetate was generated by NAA and INN, unlike in control. IAA reduced a-thujone (1.19 vs 0.94 for control and treated, respectively) but NAA eradicated it completely. Several compounds, i.e., nos. $7,9,10,12,14$, $16,18,19,21,22,27,29,30,41,42,46,52,56$ were eradicated completely when the leaves were treated with NAA and IAA hormones. The other compounds in Table 1 (c), i.e., nos. 64 - 70, were produced following treatment with NAA. These compounds have previously not reported for the plant.

\section{DISCUSSION}

Sixty components were identified in the oil. Longifolene is a naturally occurring sesquiterpene whose role in a number of oxidation and rearrangement reactions, because of its significance in the fragrance industry, has been intensively investigated [8]. It was eradicated in the plant treated IAA in comparison with blank. NAA increased it about 5 times. Elemene is a mixture of sesquiterpene compounds extracted from ginger plants curcuma, with outstanding advantages of a broad anti-tumor spectrum, curative effect, and less adverse reaction [9]. There are three major components of $\beta, y, \delta$ isomers. Recently, elemene emulsion has been used widely in clinical treatment for many malignancies and tumors [10].

Both NAA and IAA significantly increased $\gamma$ Elemene in the plant oil. $\delta$ - Elemene has been 
eradicated in plant-treated NAA but decreased by IAA. Aromadendrene is the main constituent of the distillation tail of the essential oil of Eucalyptus globulus. Aromadendrene is a cheap and abundantly available chiral starting material for organic syntheses. It has been shown that many other useful intermediates and natural products can be obtained from this compound [11]. Aromadendrene was increased 7 times in content by treating with IAA. NAA eradicated it completely. $\beta$-Selinene is the major sesquiterpene of calamondin fruits. It was increased 12 times by treating with IAA. NAA eradicated it completely. a-Humulene and transcaryophyllene are plant sesquiterpenes with pronounced anti-inflammatory properties [12].

a-Humulene exhibits marked antiallergic and anti-inflammatory properties [13]. It was not detected in control groups but both NAA and IAA significantly induced its production in treated plants. $\alpha$-Thujone is the toxic monoterpenoid in some herbal medicines and is reported to have acute toxic effect and causes convulsions [14]. Long-term ingestion of plants containing this compound can cause hallucinations, sleeplessness, tremor, convulsions, and paralysis, a syndrome called absinthism. Animal experiments have shown that $\alpha$-thujone is neurotoxic [14]. The presence of $\alpha$-Thujone in the leaf can increase the plant's toxicity as was reported recently [1].

\section{CONCLUSION}

It seems that treatment of plants with some growth hormones (NAA and IAA) would be a useful method for modifying the chemical composition of $S$. ebulus leaf essential oil. NAA and IAA significantly influence the concentration and composition of the essential oil of $S$. ebulus.

\section{REFERENCES}

1. Ebrahimzadeh MA, Mahmoudi M, Karami M, Saeedi SS, Ahmadi AH, Salimi E. Separation of active and toxic portions in Sambucus ebulus. Pak J Biol Sci 2007; 10(22): 4171-4173.

2. Ebrahimzadeh MA, Mahmoudi M, Salimi E. Antiinflammatory activity of sambucus ebulus hexane extracts. Fitoterapia 2006; 77: 146-148.

3. Ebrahimzadeh MA, Ehsanifar S, Eslami B. Sambucus ebulus elburensis fruits: $A$ good source for antioxidants. Pharmacog Mag 2009; 4(19): 213-218.

4. Ebrahimzadeh MA, Nabavi SF, Nabavi SM. Antioxidant activities of methanol extract of Sambucus ebulus $L$. flower. Pak J Biol Sci 2009; 12(5): 447-450.

5. Schmelz EA, Engelberth J, Alborn HT, O'Donnell $P$, Sammons $M$, Toshima $H$, Tumlinson $\mathrm{JH}$. Simultaneous analysis of phytohormones, phytotoxins, and volatile organic compounds in plants. Proc Natl Acad Sci 2003; 100: 10552-10557.

6. Eckhardt NA. New insights into auxin biosynthesis. Plant Cell 2001; 13: 1-3.

7. Adams RP, Identification of Essential Oil Components by Gas Chromathography/ Mass Spectrometry, Allured Publishing Corporation, Carol Stream, IL, USA, 2001.

8. Dimitrov V, Linden A, Hesse M. Chiral ferrocenes derived from (+) - longifolene- determination of the configuration by NMR spectroscopy and $X$-ray crystallography Tetrahedron: Asymmetry 2001; 12: 1331-1335.

9. Sun MG, Li SB, Zhou L. Chemical constituents of active pharmaceutical ingredients of elemene. J Shenyang Pharm Univ 2009; 26(8): 620-622.

10. Yao SJ, Liu BY, Lv LY. Studies of reducing poison and increasing effect of elemene emulsions on immune function of tumor-bearing mice after chemiotherapy. Arch Trad Chin Med 2006; 24(3): 456-457.

11. Gijsen HJM, Wijnberg JB, de Groot $A$. Structure, Occurrence, biosynthesis, biological activity, synthesis and chemistry of aromadendrane sesquiterpenoids. Prog Chem Nat Prod. 1995; 64: 149-193.

12. Fernandes ES, Passos GF, Medeiros R, da Cunha FM, Ferreira J, Campos MM, Pianowski LF, Calixto JB. Anti-inflammatory effects of compounds alphahumulene and (-)-trans-caryophyllene isolated from the essential oil of Cordia verbenacea. Eur $J$ Pharmacol 2007; 569: 228-236.

13. Rogerio $A P$, Andrade EL, Leite DFP, Figueiredo $C P$, Calixto JB. Preventive and therapeutic antiinflammatory properties of the sesquiterpene $\alpha$ humulene in experimental airways allergic inflammation. Brit J Pharmacol 2009; 158: 10741087.

14. Deiml T, Haseneder R, Zieglgansberger W, Rammes G, Eisensamer $B$, Rupprecht $R$, Hapfelmeier $G$. $\alpha-$ Thujone reduces 5-HT3 receptor activity by an effect on the agonist-induced desensitization. Neuropharmacol 2004; 46: 192-201. 